\title{
HUBUNGAN TINGKAT PENGETAHUAN REMAJA TENTANG KESEHATAN \\ REPRODUKSI DENGAN PERILAKU SEKS BEBAS PADA SISWA \\ KELAS XI SMA NEGERI 6 SURAKARTA
}

\author{
Febry Heldayasari Prabandari , Tri Budi Rahayu \\ Program Studi D3 Kebidanan STIKes Guna Bangsa Yogyakarta \\ Email: pepifebry@yahoo.com ${ }^{*}$, triarahayu88@gmail.com
}

Latar Belakang: Angka aborsi di Indonesia diperkirakan mencapai 2,3 juta per tahun, sekitar 750.000 diantaranya dilakukan oleh remaja. Dari hasil penelitian pada remaja pada sepuluh SMA di Surakarta tahun 2005 ditemukan bahwa 30\% laki-laki yang berpacaran telah melakukan hubungan seksual, sedangkan untuk perempuan sebanyak $5 \%$. Kurangnya pemahaman tentang perilaku seksual pada masa remaja adalah salah satu penyebabnya.

Tujuan Penelitian: Penelitian bertujuan untuk mengetahui hubungan pengetahuan tentang kesehatan reproduksi dengan perilaku seks bebas di SMA Negeri 6 Surakarta.

Metode Penelitian: Penelitian menggunakan desain observational analitik dengan rancangan cross sectional. Teknik sampling yang digunakan simple random sampling dengan jumlah sampel 177 siswa. Analisa data menggunakan uji statistik korelasi Kendall $\operatorname{Tau}(\mathrm{T})$.

Hasil Penelitian: 125 siswa $(70.6 \%)$ memiliki pengetahuan yang baik tentang kesehatan reproduksi dan 52 siswa $(75,0 \%)$ memiliki perilaku yang baik dalam pergaulan seks bebas. Dari hasil analisa data dengan Kendall Tau diperoleh $Z_{\text {hitung }}(9,96)>z_{\text {tabel }}(1,96)$. Simpulan: ada hubungan yang signifikan antara pengetahuan remaja tentang kesehatan reproduksi dengan perilaku seks bebas.

Kata Kunci: pengetahuan kesehatan reproduksi, perilaku seks bebas

\section{PENDAHULUAN}

WHO (World Health Organization) memperkirakan di seluruh dunia setiap tahun terjadi 20 juta kejadian aborsi yang tidak aman (unsafe abortion), 95\% diantaranya terjadi di negara-negara berkembang. Sekitar 78.000 (13\%) dari total perempuan melakukan atau mendapatkan tindakan aborsi yang tidak aman berakhir dengan kematian. Angka aborsi di Indonesia diperkirakan mencapai
2,3 juta per tahun, sekitar 750.000 diantaranya dilakukan oleh remaja. ${ }^{1}$

Hasil penelitian mengenai perilaku seksual remaja pada sepuluh SMA baik negeri maupun swasta di Surakarta tahun 2005 terhadap 1.250 orang (611 subjek laki-laki dan 639 subjek perempuan ) ditemukan bahwa 30\% laki-laki yang berpacaran telah melakukan hubungan seksual, sedangkan untuk perempuan sebanyak $5 \%$. Dapat dikatakan bahwa setiap ada 3 anak laki-laki yang berpacaran, satu diantaranya telah 
melakukan hubungan seksual dan mereka rata-rata mulai melakukannya di kelas dua dan tiga. Dengan hasil demikian, tentunya dapat diperkirakan bahwa seks bebas di perguruan tinggi lebih gila dibandingkan di SMA. ${ }^{2}$

Kurangnya pemahaman tentang perilaku seksual pada masa remaja sangat merugikan bagi remaja sendiri termasuk keluarganya, sebab pada masa ini remaja mengalami perkembangan yang penting yaitu kognitif, emosi, sosial dan seksual, perkembangan ini akan berlangsung sekitar 12 tahun sampai 20 tahun. Kurangnya pemahaman ini disebabkan oleh beberapa faktor antara lain: adat istiadat, budaya, agama dan kurangnya informasi dari sumber yang benar. Kurangnya pemahaman ini akan mengakibatkan berbagai dampak yang justru amat merugikan kelompok remaja dan keluarganya. ${ }^{1}$

Dampak yang diakibatkan oleh perilaku seksual antara lain adalah timbulnya masalah psikologis yang sangat serius, seperti rasa bersalah, depresi, marah, dan agresi. Sementara akibat psikososial yang timbul akibat perilaku seksual antara lain adalah ketegangan mental dan kebingungan akan peran sosial yang tiba-tiba berubah, misalnya pada kasus remaja yang hamil di luar nikah. Belum lagi tekanan dari masyarakat yang mencela dan menolak keadaan tersebut. Selain itu resiko yang lain adalah terganggunya kesehatan yang bersangkutan, resiko kelainan janin dan tingkat kematian bayi yang tinggi. Disamping itu tingkat putus sekolah remaja hamil juga sangat tinggi, hal ini disebabkan rasa malu remaja dan penolakan sekolah menerima kenyataan adanya murid yang hamil diluar nikah. Masalah ekonomi juga akan membuat permasalahan ini menjadi semakin rumit dan kompleks. ${ }^{3}$

Pendidikan seksual merupakan cara pengajaran atau pendidikan yang dapat menolong remaja untuk menghadapi masalah hidup yang bersumber pada dorongan seksual. Dengan demikian pendidikan seksual ini bermaksud untuk menerangkan segala hal yang berhubungan dengan seks dan seksualitas dalam bentuk yang wajar. ${ }^{4}$
Tujuan umum dari penelitian ini adalah untuk mengetahui hubungan tingkat pengetahuan remaja tentang kesehatan reproduksi dengan perilaku seks bebas pada siswa kelas XI SMA Negeri 6 Surakarta. Tujuan khusus dari penelitian ini adalah: 1) Untuk Mengetahui tingkat pengetahuan remaja tentang kesehatan reproduksi di SMA Negeri 6 Surakarta; 2) Mengetahui perilaku remaja terhadap pergaulan seks bebas di SMA Negeri 6 Surakarta; 3) Mengetahui hubungan tingkat pengetahuan remaja tentang kesehatan reproduksi dengan perilaku seks bebas pada siswa kelas XI SMA Negeri 6 Surakarta.

Berdasar latar belakang di atas dapat diambil rumusan masalah yaitu "Adakah hubungan tingkat pengetahuan remaja tentang kesehatan reproduksi dengan perilaku seks bebas pada siswa kelas XI SMA Negeri 6 Surakarta?

Manfaat dari penelitian ini yaitu diharapkan dapat mengembangkan ilmu pengetahuan khususnya kesehatan reproduksi tentang bagaimana hubungan antara tingkat pengetahuan remaja tentang kesehatan reproduksi dengan perilaku seks bebas serta sebagai masukan untuk SMA Negeri 6 Surakarta memberikan pengetahuan tentang kesehatan reproduksi yang benar sebagai sarana meningkatkan informasi dan pengetahuan bagi siswa di sekolah tersebut.

Penelitian sejenis yang dilakukan oleh Widiastuti (2006) dalam penelitiannya yang berjudul "Hubungan Berpikir Positif dengan Perilaku Seksual Pra Nikah Remaja di SMA Veteran I Sukoharjo". Penelitian ini menggunakan metode observasional analitik dengan rancangan cross sectional. Populasi dalam penelitian ini adalah siswa siswi kelas SMA Veteran 1 Sukoharjo kelas 3, tehnik pengambilan sampel menggunakan cluster random sampling dan sampelnya berjumlah 79 responden. Tehnik pengumpulan data dengan wawancara. Penelitian ini menyebutkan bahwa tidak ada hubungan antara berpikir positif dengan perilaku seksual pada remaja. ${ }^{5}$ 
METODE PENELITIAN

Desain penelitian ini adalah observasional analitik yaitu peneliti mencoba untuk mencari hubungan antara variabel bebas (faktor resiko) dengan variabel tergantung (efek) dengan cara dengan metode pendekatan waktu cross sectional model yaitu pendekatan dimana sebab atau risiko dan akibat atau kasus yang terjadi pada obyek penelitian diukur atau dikumpulkan secara stimultan (dalam waktu yang bersamaan). ${ }^{6}$

Penelitian ini dilaksanakan di SMA Negeri 6 Surakarta. Penelitian akan dilakukan pada bulan Juni 2015. Populasi dalam penelitian ini adalah siswa-siswi kelas XI di SMA Negeri 6 Surakarta tahun 2015 sejumlah 340 siswa. Apabila subjeknya kurang dari 100 lebih baik diambil semua sehingga penelitiannya merupakan penelitian populasi. Tetapi jika jumlah subjeknya besar, dapat diambil antara $10-15 \%$ atau $20-25 \%$ atau lebih. Maka dalam penelitian ini diambil sampel $20 \%$ dari jumlah populasi yaitu sebanyak 68 siswa. $^{7}$

Tehnik sampling adalah tehnik pengambilan sampel. Dalam penelitian ini menggunakan tehnik simple random sampling yaitu suatu tehnik penetapan sampel dengan acak tanpa memperhatikan strata yang ada dalam populasi dengan menggunakan lotere dan memberi angka. ${ }^{8}$

Dalam penelitian ini terdapat dua variabel yang diteliti yaitu variabel bebas (tingkat pengetahuan remaja tentang kesehatan reproduksi) dan variabel terikat (perilaku remaja dengan seks bebas). Skala yang digunakan adalah skala ordinal. Kategorinya terdiri dari: a. Baik $76-100 \%$, b. Cukup 56-75\%, c. Kurang $\leq$ $56 \% .^{9}$

Uji validitas untuk mengukur tingkat pengetahuan dalam penelitian ini menggunakan teknik korelasi point biserial bersifat dikotomi. Item dinyatakan valid jika $\quad r_{\text {hitung }} \geq r_{\text {tabel }}$ pada taraf signifikansi $5 \%$. Dari hasil uji validitas didapatkan 5 pertanyaan tidak valid. Uji validitas untuk mengukur tingkat perilaku dalam penelitian ini menggunakan teknik Product
Moment karena data tipe skala pengukuran yang digunakan adalah skala Likert. Uji validitas dikatakan valid jika $r_{\text {hitung }}>r_{\text {tabel. }}$. Dari hasil uji validitas didapatkan 1 pertanyaan tidak valid.

Rumus yang digunakan untuk mengukur reliabilitas dari tingkat pengetahuan adalah rumus Kuder Richardson-20. Jika $r_{\text {hitung }}>r_{\text {tabel }}$ maka disimpulkan bahwa instrumen yang digunakan adalah reliabel. Dari hasil perhitungan didapatkan $r_{i}$ (hitung) 0.994 > dengan $r$ tabel nilai 0.514 maka dikatakan bahwa instrumen penelitian yang digunakan adalah reliabel. Rumus yang digunakan untuk mengukur reliabilitas dari perilaku menggunakan rumus Alfa Cronbach. Dari hasil perhitungan didapatkan $r_{1}$ atau $\alpha$ adalah 0.959 maka dapat dikatakan bahwa instrumen penelitian mempunyai tingkat reliabilitas tinggi.

Tehnik pengolahan data melalui tahap-tahap berikut : Penyuntingan (Editing), Pengkodean (Coding) Tabulating (Tabulating), Analisa Data. Analisa data menggunakan program SPSS for Window's. Rumus Analisis yang digunakan yaitu Kendal Tau, datanya berbentuk ordinal dengan jumlah sampel lebih dari sepuluh rumus dasar yang digunakan:

$$
T=\frac{\sum A-\sum B}{\frac{N(N-1)}{2}}
$$

Keterangan:

$\mathrm{T}$ : koefisien korelasi Kendal Tau yang besarnya $(-1<0<1)$

$\sum A$ : jumlah rangking atas

$\sum B$ : jumlah rangking bawah

$\mathrm{N}$ : jumlah anggota sample

Untuk dapat memberikan tafsiran apakah harga tersebut signifikan atau tidak, maka dapat menggunakan ketentuan bahwa bila z hitung lebih besar dari z tabel, maka koefisien korelasi yang ditemukan adalah signifikan. Selanjutnya $Z$ hitung dibandingkan dengan $Z$ tabel ( $\alpha$ $=5 \%$ uji dua pihak). Apabila $Z$ hitung $>Z$ tabel, hubungan signifikan (Ho ditolak, $\mathrm{Ha}$ diterima). ${ }^{8}$ 


\section{HASIL DAN PEMBAHASAN}

Karakteristik umum responden dapat dikelompokkan sebagai berikut:

a. Berdasarkan Umur

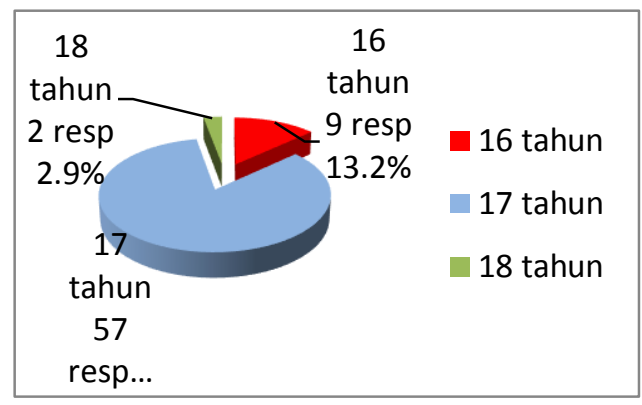

Gambar 1. Karakteristik Responden Berdasarkan Umur

Berdasarkan Gambar di atas menunjukkan bahwa dari 68 responden, umur responden terbanyak adalah 17 tahun, yaitu 57 responden $(83,8 \%)$, dan paling rendah umur 18 tahun sebanyak 2 responden (2,9\%).

b. Berdasarkan Jenis Kelamin

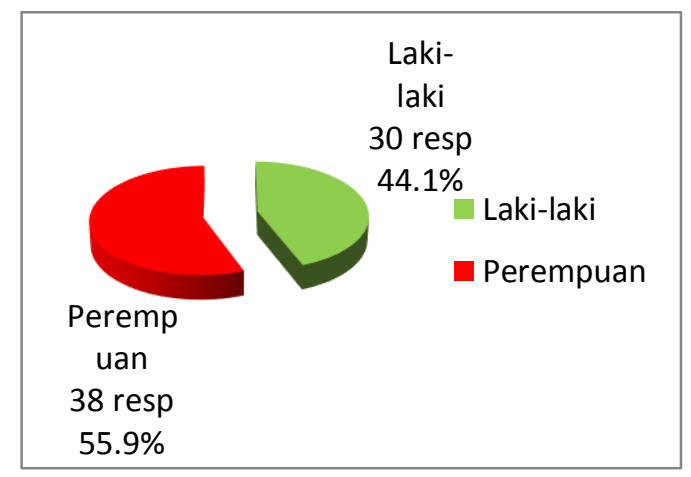

Gambar 2. Karakteristik Responden Berdasarkan Jenis Kelamin

Berdasarkan Gambar di atas memperlihatkan bahwa dari 68 responden yang berjenis kelamin lakilaki sebanyak 30 responden $(44,1 \%)$, dan yang berjenis kelamin perempuan sebanyak 38 responden $(55,9 \%)$. c. Berdasarkan Pernah Tidaknya Mendapat Informasi Kesehatan Reproduksi dan Seks Bebas

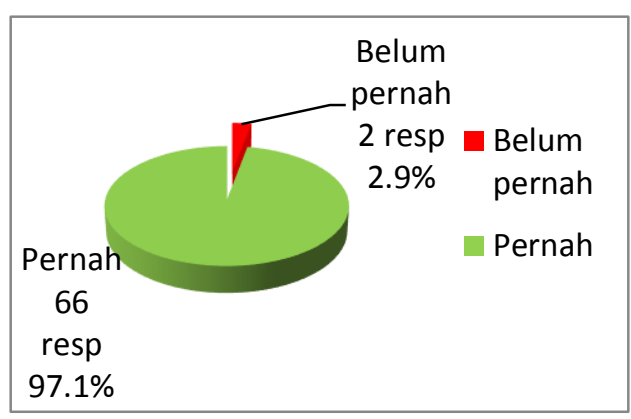

Gambar 3. Karakteristik Responden Berdasarkan Pernah Tidaknya Mendapat Informasi Kesehatan Reproduksi dan Seks Bebas

Gambar 3 menunjukkan dari 68 responden sebanyak 66 responden $(97,1 \%)$ sudah pernah mendapatkan informasi tentang kesehatan reproduksi dan seks bebas dan 2 responden $(2,9 \%)$ belum pernah mendapatkan informasi tentang kesehatan reproduksi dan seks bebas.

d. Sumber Informasi tentang Kesehatan Reproduksi dan Seks Bebas

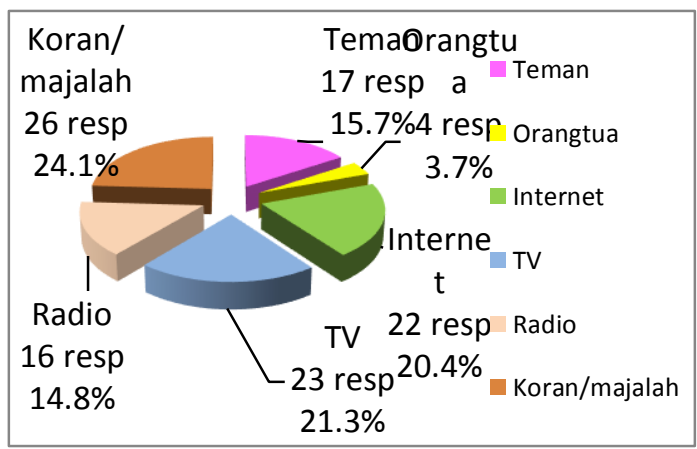

Gambar 4. Sumber Informasi tentang Kesehatan Reproduksi dan Seks Bebas

Gambar 5 diketahui bahwa dari 68 responden responden paling banyak mempunyai tingkat pengetahuan baik yaitu 48 responden $(70,6 \%)$ dan responden paling sedikit mempunyai tingkat pengetahuan kurang yaitu 1 responden $(1,5 \%)$. 
e. Karakteristik Responden Berdasarkan Tingkat Pengetahuan tentang Kesehatan Reproduksi

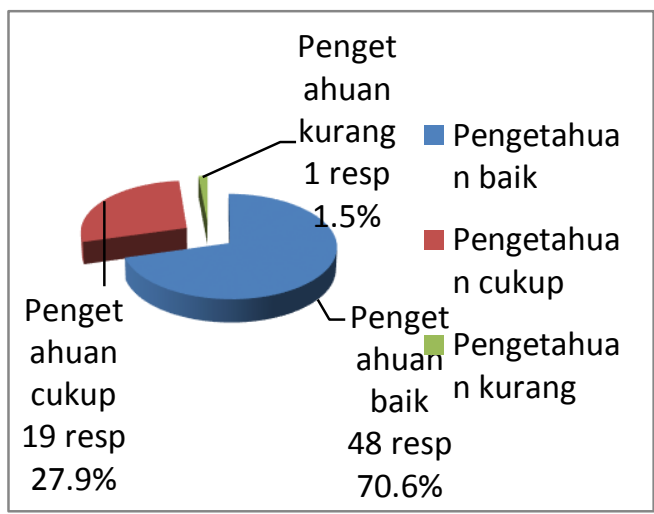

Gambar 5. Karakteristik Responden Berdasarkan Perilaku Seks Bebas

Dari gambar di atas diketahui bahwa dari 68 responden responden paling banyak mempunyai tingkat pengetahuan baik yaitu 48 responden $(70,6 \%)$ dan responden paling sedikit mempunyai tingkat pengetahuan kurang yaitu 1 responden (1,5\%).

f. Karakteristik Responden Berdasarkan Perilaku tentang Seks Bebas

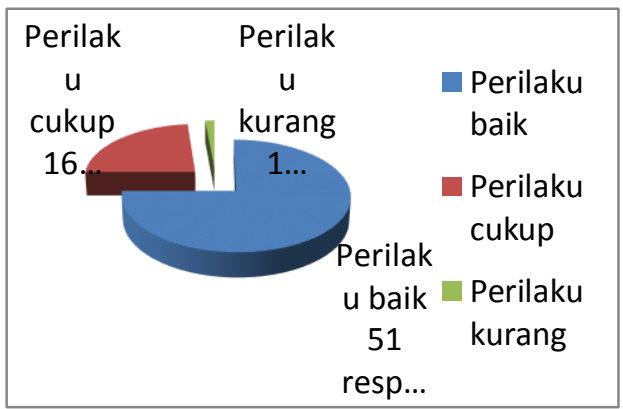

Gambar 6. Karakteristik Responden Berdasarkan Perilaku Seks Bebas

Berdasarkan Gambar di atas, menunjukkan bahwa dari 68 responden responden paling banyak mempunyai perilaku baik, yaitu 51 responden $(75,0 \%)$ dan paling sedikit dengan perilaku kurang, yaitu 1 responden $(1,5 \%)$.

g. Analisis Hubungan Tingkat Pengetahuan Remaja tentang Kesehatan Reproduksi dengan Perilaku Seks Bebas
Tabel 1. Analisis Hubungan Tingkat Pengetahuan Remaja tentang Kesehatan Reproduksi dengan Perilaku Seks Bebas

\begin{tabular}{|c|c|c|c|c|c|}
\hline & & & Perilak & & \\
\hline Penge & ahuan & Baik & Cukup & Kurang & Total \\
\hline Baik & Count & 47 & 1 & 0 & 48 \\
\hline & $\begin{array}{l}\% \text { of } \\
\text { Total }\end{array}$ & $\begin{array}{c}69.1 \\
\%\end{array}$ & $1.5 \%$ & $.0 \%$ & $70.6 \%$ \\
\hline Cukup & Count & 4 & 15 & 0 & 19 \\
\hline & $\begin{array}{l}\% \text { of } \\
\text { Total }\end{array}$ & $5.9 \%$ & $22.1 \%$ & $.0 \%$ & $27.9 \%$ \\
\hline Kurang & Count & 0 & 0 & 1 & 1 \\
\hline & $\begin{array}{l}\% \text { of } \\
\text { Total }\end{array}$ & $.0 \%$ & $.0 \%$ & $1.5 \%$ & $1.5 \%$ \\
\hline Total & Count & 51 & 16 & 1 & 68 \\
\hline & $\begin{array}{l}\% \text { of } \\
\text { Total }\end{array}$ & $\begin{array}{c}75.0 \\
\%\end{array}$ & $23.5 \%$ & $1.5 \%$ & $100.0 \%$ \\
\hline
\end{tabular}

Hubungan tingkat pengetahuan tentang kesehatan reproduksi dengan perilaku seks bebas, didistribusikan sebagai berikut:

1) Responden dengan tingkat pengetahuan baik didistribusikan, sebagai berikut: berperilaku baik 47 anak $(69,1 \%)$, berperilaku cukup 1 anak $(1,5 \%)$, dari total responden dengan pengetahuan baik 48 anak $(70,6 \%)$.

2) Responden dengan tingkat pengetahuan cukup didistribusikan, sebagai berikut: berperilaku baik 4 anak $(5,9 \%)$, berperilaku cukup 15 anak $(22,1 \%)$, dari total responden dengan pengetahuan cukup 19 anak $(27,9 \%)$

3) Semua responden yang berpengetahuan kurang memiliki perilaku kurang sebanyak 1 orang $(1,5 \%)$.

Hasil uji korelasi dengan menggunakan Kendall Tau $(\tau)$ didapatkan nilai $\tau 0,826$ karena jumlah sampel $>40$, maka untuk uji hipotesis dengan cara mencari nilai $Z$ (normalitas) kemudian 
dibanding pada $Z_{\text {tabel }}$ pada 1-a $\left(Z_{1-\alpha}\right)$. Berdasarkan hasil nilai $\tau$ pada $N=68$ dengan tingkat kepercayaan 95\% didapatkan $Z_{\text {hitung }}=9,96$ dan $Z_{\text {tabel }}(1-\alpha)=$ 1,96 karena $Z_{\text {hitung }}>Z_{\text {tabel }}(9,96>1,96)$, maka dapat disimpulkan Ho ditolak dan $\mathrm{Ha}$ diterima, sehingga ada hubungan antara tingkat pengetahuan tentang kesehatan reproduksi dengan perilaku seks bebas.

Menurut Green, perilaku dibentuk oleh banyak hal, baik faktor predisposisi, pendukung maupun faktor pendorong. Faktor predisposisi yang terwujud dalam tingkat pendidikan, sosial ekonomi, pengalaman, nilai atau keyakinan. Faktor pendukung yang terwujud dalam lingkungan fisik, tersedia atau tidak tersedianya fasilitas atau sarana kesehatan. Faktor pendorong yang terwujud dalam sikap dan perilaku petugas kesehatan, atau petugas yang lain, yang merupakan kelompok referensi dari perilaku masyarakat. ${ }^{4}$

Hasil penelitian membuktikan pendapat Green benar, ada korelasi atau hubungan antara pengetahuan dengan perilaku. Hasil penelitian menunjukkan responden dengan pengetahuan tentang kesehatan reproduksi yang baik akan beperilaku baik pula, sedang responden dengan pengetahuan kurang berperilaku kurang baik pula.

Baiknya tingkat pengetahuan responden mengenai kesehatan reproduksi dan seks bebas adalah suatu yang wajar, mengingat semakin mudahnya akses informasi tentang kesehatan, baik yang diperoleh dari sekolah atau dari media cetak maupun elektronik. Hasil penelitian menunjukkan mayoritas responden sudah pernah mendapatkan informasi tentang kesehatan reproduksi dan seks bebas.

\section{KESIMPULAN DAN SARAN}

Penelitian yang dilakukan di kelas XI SMA Negeri 6 Surakarta, dengan tujuan meneliti hubungan antara tingkat pengetahuan remaja tentang kesehatan reproduksi dengan perilaku seks bebas, dapat diambil kesimpulan sebagai berikut:
1. Mayoritas responden mempunyai tingkat pengetahuan baik, yaitu 48 responden $(70,6 \%)$.

2. Mayoritas responden mempunyai perilaku yang baik, yaitu 51 responden (75,0\%).

3. Ada hubungan yang signifikan antara tingkat pengetahuan remaja tentang kesehatan reproduksi dengan perilaku seks bebas.

Berdasarkan hasil penelitian yang diperoleh, maka saran yang dapat penulis sampaikan antara lain:

1. Bagi SMA Negeri 6 Surakarta

a. Dapat lebih memberikan pengetahuan tentang kesehatan reproduksi kepada siswa dengan cara memasukkan pengetahuan tentang kesehatan reproduksi ke dalam materi pembelajaran atau bimbingan konseling.

b. Mengadakan pertemuan dengan orang tua siswa agar mereka dapat memberikan informasi tentang kesehatan reproduksi dan menanamkan nilai-nilai agama serta lebih mengawasi pergaulan anak mereka sehingga hal ini dapat mengurangi tingkat kenakalan remaja.

2. Bagi Peneliti Selanjutnya

Mengingat keterbatasan penelitian diharapkan agar peneliti selanjutnya dapat melakukan penelitian dengan menggunakan metode penelitian yang lain sehingga hasil penelitian menjadi lebih baik.

\section{DAFTAR PUSTAKA}

${ }^{[1]}$ Soetjiningsih. (2007). Tumbuh Kembang Remaja dan Permasalahannya. Jakarta: CV Sagung Seto.

${ }^{[2]}$ Taufik. (2008). http://taufikblog.friendster.com, diperoleh tanggal 15 Januari 2009.

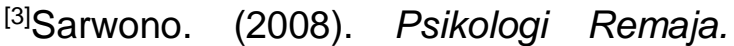
Jakarta: PT Raja Grafindo Persada.

${ }^{[4]}$ Notoatmodjo, S. (2007). Promosi Kesehatan dan IImu Perilaku. Jakarta: PT Rineka Cipta. 
[5]Widiastuti, T. (2006). Hubungan Berpikir Positif dengan Perilaku Seksual Pranikah pada Remaja di SMA Veteran I Sukoharjo. Surakarta: FK UMS.

${ }^{[6]}$ Notoatmodjo, S. (2005). Metodologi Penelitian Kesehatan. Jakarta: PT Rineka Cipta.

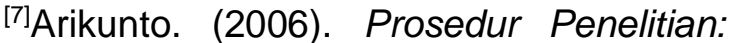
Suatu Pendekatan Praktek. Jakarta: PT Rineka Cipta

${ }^{[8]}$ Sugiyono. (2007). Statistika Untuk Penelitian. Bandung: Alfa Beta.

[9]Nursalam. (2003). Konsep dan Penerapan Metodologi Penelitian IImu Keperawatan. Jakarta: Salemba Medika. 